\title{
Cooling System Economy in Ethanol Production Using Thermotolerant Yeast Kluyveromyces Sp. IIPE453
}

\author{
Sachin Kumar ${ }^{1,2,3, *}$, Pratibha Dheeran ${ }^{2,5}$, Surendra P. Singh ${ }^{4}$, Indra M. Mishra ${ }^{3}$, Dilip K. Adhikari ${ }^{2}$ \\ ${ }^{1}$ Sardar Swaran Singh National Institute of Renewable Energy, Kapurthala, India \\ ${ }^{2}$ Biotechnology Area, Indian Institute of Petroleum, Dehradun, India \\ ${ }^{3}$ Department of Chemical Engineering, Indian Institute of Technology, Roorkee, India \\ ${ }^{4}$ Department of Paper Technology, Indian Institute of Technology, Roorkee, Saharanpur Campus, India \\ ${ }^{5}$ SRM Research Institute, SRM University, Kattankulathur, Tamilnadu, India \\ *Corresponding author: sachin.biotech@gmail.com
}

Received March 11, 2013; Revised April 18, 2013; Accepted April 23, 2013

\begin{abstract}
The growth of thermotolerant/ thermophilic ethanol producing yeast and the fermentation processes using sugary substrates are exothermic processes. If the fermenters are heat insulated, the requirement of heat for maintaining the fermentation broth for ethanol production may be reduced considerably. The heat generated due to growth of thermotolerant yeast Kluyveromyces sp. IIPE453 was found to be $652 \mathrm{~kJ} \mathrm{~mol}^{-1}$ at $50^{\circ} \mathrm{C}$ using glucose as a substrate. The heat generated due to ethanol formation by Kluyveromyces sp. IIPE453 was found to be $132.54 \mathrm{~kJ}$ $\mathrm{mol}^{-1}$ of sugar consumed or $67.84 \mathrm{~kJ} \mathrm{~mol}^{-1}$ of ethanol produced at $50^{\circ} \mathrm{C}$ using sugarcane molasses as substrate. This heat would be sufficient for maintaining the desired temperature, if insulated fermentation systems are used. Therefore, no additional heat would be required to maintain the temperature in fermentation process by thermotolerant yeast at $50^{\circ} \mathrm{C}$.
\end{abstract}

Keywords: metabolic heat, bioreactor, ethanol fermentation, thermotolerant yeast, cooling water

\section{Introduction}

Most of the potential ethanologens that are in industrial use belong to mesophilic group $\left(28-35^{\circ} \mathrm{C}\right)[1,2,3,4,5]$. However, bioethanol production by thermophiles has certain advantages over mesophiles and it needs to be investigated for ethanol production. Solvent tolerance, energy savings through reduced cooling costs, higher saccharification and fermentation rates, continuous ethanol removal and the reduced risk of contamination have stimulated a search for thermophilic or thermotolerant yeasts $[6,7,8,9,10]$. Less energy would be required for mixing of fermentation broth containing sugar, product and cell mass and product recovery in thermophilic fermentations because of lower viscosity, surface tension, higher vapor pressure and increased solubility of organic compounds [11]. Ethanol production at high temperature is effective in tropical countries where average day-time temperatures $\left(30-40^{\circ} \mathrm{C}\right)$ are usually high throughout the year $[9,12]$.

The heat generation and its regulation accompanied by metabolic turnover is an inherent property of living systems $[13,14]$.

$$
\begin{aligned}
& \mathrm{C}_{6} \mathrm{H}_{12} \mathrm{O}_{6}+\text { Microorganisms } \\
& \quad \rightarrow 2 \mathrm{C}_{2} \mathrm{H}_{5} \mathrm{OH}+2 \mathrm{CO}_{2}+\Delta \mathrm{H}_{r}
\end{aligned}
$$

Where, $\Delta H_{r}$ is heat generated due to biological reactions $(\mathrm{kJ})$. The bacterium Zymomonas mobilis and yeast Saccharomyces cerevisiae are known to gain the energy required for growth and maintenance under anaerobic conditions by substrate phosphorylation processes through the Entner-Doudoroff pathway and glycolysis, respectively [15]. Theerarattananoon et al. [16] reported overall metabolic heat generation $43 \mathrm{~kJ} \mathrm{~mol}^{-1}$ glucose consumed or $32 \mathrm{~kJ} \mathrm{~mol}^{-1}$ ethanol produced during fermentation using $S$. cerevisiae at $25^{\circ} \mathrm{C}$, when initial glucose concentration was kept at $300 \mathrm{~g}^{-1}$ glucose.

The heat loss to environment is negligible in the industrial scale bioreactors because these are operated nearly adiabatically due to much lower surface to volume ratio compared to laboratory-scale bioreactors [17], requiring huge quantity of cooling water to maintain optimum temperature. Approximately $60-70 \%$ of total chilling water load is used in bioreactors for ethanol production by using mesophiles [18]. In tropical countries, the cooling water at $28^{\circ} \mathrm{C}$ is used to maintain the fermentation temperature at $32^{\circ} \mathrm{C}$ in bioreactor. Heat generation by exothermic sugar fermentation (Eq.(1)) by thermophilic/thermotolerant microorganisms has an impact on the net heat balance vis-à-vis cooling water requirement in such fermentation process.

In the present paper, the metabolic heat generation on sugar consumption or ethanol production by the thermotolerant yeast Kluyveromyces sp. IIPE453 is reported and the advantage on cooling water requirement over $S$. cerevisiae is compared.

\section{Materials and Methods}




\subsection{Microorganisms and Culture Conditions}

A thermotolerant yeast, Kluyveromyces sp. IIPE453 (MTCC 5314) [19] was grown in Bioflow-110 bioreactor (working volume 5 liters) on medium SM containing $\mathrm{g} \mathrm{l}^{-1}$, di-sodium hydrogen ortho phosphate, 0.15 ; potassium dihydrogen ortho phosphate, 0.15; ammonium sulphate, 2.0; yeast extract, 1.0; glucose 20 . The temperature and $\mathrm{pH}$ were controlled at $50^{\circ} \mathrm{C}$ and 5.0 , respectively. The aeration rate in the bioreactor was provided at $1 \mathrm{vvm}$ and the agitation was maintained at 350rpm.2.1.1. Front Matter

\subsection{Fermentation Conditions}

The batch fermentation using the yeast Kluyveromyces sp. IIPE453 was carried out in a Bioflow-110 bioreactor (working volume 2 liters) using molasses as substrate, which contained the initial reducing sugar concentration of $300 \mathrm{~g} \mathrm{l}^{-1}$ [20]. The components (in $\mathrm{g} \mathrm{l}^{-1}$ ), di-sodium hydrogen ortho phosphate, 0.15 ; potassium di-hydrogen ortho phosphate, 0.15 ; ammonium sulphate, 1.0; yeast extract, 1.0 were mixed in the molasses solution and sterilized for $15 \mathrm{~min}$ at $121^{\circ} \mathrm{C}$. The temperature and $\mathrm{pH}$ were controlled at $50^{\circ} \mathrm{C}$ and 5.0 , respectively. The agitation was maintained at $200 \mathrm{rpm}$. The initial dry cell weight (DCW) was kept at $4.5 \mathrm{~g} \mathrm{l}^{-1}$.

\subsection{Bioreactor}

Bioflow-110 bioreactor of working volume 2 liters was used in the study. The bioreactor vessel was made of glass with internal diameter of $12.8 \mathrm{~cm}$, height of broth in the reactor of $17 \mathrm{~cm}$ and the thickness of glass of $0.3 \mathrm{~cm}$, as shown in Figure 1.

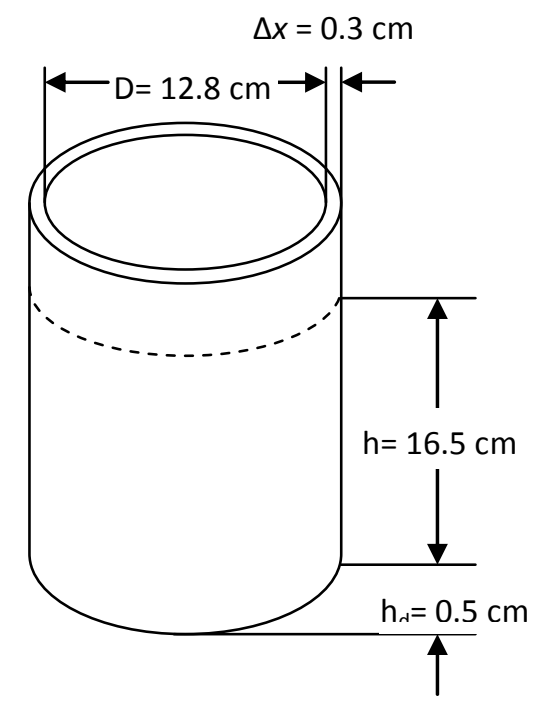

Figure 1. The illustration of bioreactor vessel

\section{Theory/Calculation}

\subsection{Heat Generation}

The ethanol fermentation process is an exothermic process. As the fermentation progresses (glucose fermentation to ethanol proceeds), the heat generated will raise the temperature of the fermentation broth. To maintain isothermal conditions, the excess heat generated is removed by using cooling coils within the reactor and/or jackets around the reactor with continuous flow of cooling medium (cold/chilled water). In a laboratory, with no fan/ventilator, the heat loss from the bioreactor surface to the surrounding air atmosphere shall take place by natural convection. If the reactor is used for cell growth, then aeration is done at a rate suitable for maintaining growth. In such a case, heat loss to the surrounding shall take place by (i) convective heat transport from the broth by bubbling air, (ii) natural convection from the reactor surface to the surrounding atmosphere, and (iii) heat loss by evaporation of water and ethanol.

The heat generation during growth or fermentation in a batch reactor can be given as:

$$
Q=m C_{p} \Delta T+Q_{\text {loss }}
$$

Where, $Q$ is the heat generated $(\mathrm{kJ})$; $\mathrm{m}$ is the mass of fermentation/growth medium solution $(\mathrm{kg}) ; C_{p}$ is the specific heat $\left(\mathrm{kJ} \mathrm{kg}^{-1} \mathrm{~K}^{-1}\right) ; \Delta T$ is the temperature difference of the fermentation broth over a time period $(\Delta \mathrm{t})$ $(\mathrm{K})$; and $Q_{\text {loss }}$ is the total heat loss from the reactor accounting for the heat loss due to aeration (during cell growth operation) and the heat loss from the reactor surface by natural convection. On differentiating Eq. (2) with respect to time, one gets

$$
\dot{Q}=\frac{d Q}{d t}=\left.m C_{p} \frac{d T}{d t}\right|_{\text {with active cells }}+\dot{Q}_{l o s s}
$$

Therefore,

$$
\dot{Q}-\dot{Q}_{\text {loss }}=\left.m C_{p} \frac{d T}{d t}\right|_{\text {with active cells }}
$$

Where, $\dot{Q}$ is the heat generated per unit time $\left(\mathrm{kJ} \mathrm{h}^{-1}\right) ; C_{p}$ is considered to be insensitive to temperature change over a small temperature difference $(\Delta T \approx 3 \mathrm{~K}) ; d T / d t$ is the slope of the curve between temperature and time, over a given time interval.

With inactive cells in the reactor, the temperature of the reactor will fall with time due to heat loss from the reactor surface to the surrounding.

Thus,

$$
\dot{Q}_{\text {loss }}=\left.m C_{p} \frac{d T}{d t}\right|_{\text {with inactive cells }}
$$

Therefore, one gets,

$$
\dot{Q}=m C_{p} \frac{d T}{d t} \mid
$$

\subsection{Heat Loss}

The heat losses in a bioreactor during operation at high temperature may take place due to (i) convective heat transport from the broth by bubbling air, (ii) natural convection from the reactor surface to the surrounding atmosphere, and (iii) heat loss by evaporation of water and ethanol. The heat losses due to radiation, conduction and $\mathrm{CO}_{2}$ are assumed to be negligible. 
The heat loss due to bubbling air and evaporation can be given as:

$$
\begin{array}{r}
\dot{Q}_{a}=\left.m C_{p} \frac{d T}{d t}\right|_{\text {with inactive cells \& without aeration }} \\
-\left.m C_{p} \frac{d T}{d t}\right|_{\text {with inactive cells \& aeration }}
\end{array}
$$

Where, $\dot{Q}_{a}$ is the heat loss due to bubbling air and evaporation $\left(\mathrm{kJ} \mathrm{h}^{-1}\right)$. [21]:

The heat loss due to natural convection can be given as

$$
\dot{Q}_{c}=U A \Delta T
$$

Where, $\dot{Q}_{c}$ is the heat loss due to natural convection $(\mathrm{kJ}$ $\left.\mathrm{h}^{-1}\right)$; $\mathrm{U}$ is the overall heat transfer coefficient $\left(\mathrm{kJ} \mathrm{h}^{-1} \mathrm{~m}^{-2} \mathrm{~K}^{-}\right.$ $\left.{ }^{1}\right)$; $\mathrm{A}$ is the surface area $\left(\mathrm{m}^{2}\right)$ and $\Delta T$ is the temperature difference between the reactor surface and the surrounding atmosphere $(\mathrm{K})$. The overall heat transfer coefficient can be given as:

$$
U=\frac{1}{\frac{1}{h_{b}}+\frac{\Delta x}{\lambda}+\frac{1}{h_{a}}}
$$

Where, $h_{b}$ and $h_{a}$ are the convection heat transfer coefficients for broth and air, respectively $\left(\mathrm{kJ} \mathrm{h}^{-1} \mathrm{~m}^{-2} \mathrm{~K}^{-1}\right)$; $\Delta x$ is the thickness of wall (m) and $\lambda$ is the thermal conductivity of material $\left(\mathrm{kJ} \mathrm{h}^{-1} \mathrm{~m}^{-1} \mathrm{~K}^{-1}\right)$.

For the natural convection, the convection coefficient $\left(h_{a}\right)$ can be given as:

$$
h_{a}=\frac{N u \lambda_{a}}{H}
$$

Where, $N u$ is the Nusselt number; $\lambda a$ is the thermal conductivity of the air $\left(\mathrm{kJ} \mathrm{h}^{-1} \mathrm{~m}^{-1} \mathrm{~K}^{-1}\right)$; and $\mathrm{H}$ is the height of the broth level in bioreactor (m). The Nusselt number can be evaluated as reported by Lienhard and Leinhard [22]:

$$
N u=0.678 R a^{1 / 4}\left(\frac{\operatorname{Pr}}{0.952+\operatorname{Pr}}\right)^{1 / 4}
$$

Where, $R a$ is the Rayleigh number; and $P r$ is the Prandtl number which can be given as:

$$
R a=\frac{g\left(\frac{1}{T_{a}}\right)\left(T_{b}-T_{a}\right) H^{3}}{v_{a} \alpha_{a}}
$$

and,

$$
\operatorname{Pr}=\frac{v_{a}}{\alpha_{a}}
$$

Where, $\mathrm{g}$ is the gravity constant $\left(\mathrm{m} \mathrm{s}^{-2}\right) ; T_{b}$ and $T_{a}$ are the temperatures of broth and surrounding atmosphere, respectively $(\mathrm{K})$; va and $\alpha \mathrm{a}$ are the kinametic viscosity and thermal diffusivity of air $\left(\mathrm{m}^{2} \mathrm{~s}^{-1}\right)$.

Surface area $(A)$ of bioreactor can be given as:

$$
A=2 \pi r h+2 \pi r_{d} h_{d}
$$

Where, $r$ and $h$ are the radius and height of the level of broth in cylindrical section, respectively (m); $r_{d}$ and $h_{d}$ are the radius and height of spherical bottom, respectively $(\mathrm{m})$. $r_{d}$ can be calculated as:

$$
r_{d}=\frac{4 h_{d}^{2}+D^{2}}{8 h_{d}}
$$

\section{Results and Discussion}

The temperature-time courses were recorded over a period of $20 \mathrm{~min}$ in lag phase (0 hour) and log phase $\left(12^{\text {th }}\right.$ hour) during the growth of yeast Kluyveromyces sp. IIPE453 at $50^{\circ} \mathrm{C}$ at $1 \mathrm{vvm}$ aeration rate (Figure 2). The temperature was not controlled during recording of the temperature-time course. As shown in Figure 2, the temperature was decreased with time during lag phase because of high rate of heat loss to surrounding atmosphere. The lower rate of heat loss was observed during log phase than that of lag phase, shows the heat generation due to the growth of yeast. The heat generation due to growth of yeast was calculated using Eq. (6), which was found to be $26.1 \mathrm{~kJ} \mathrm{~h}^{-1}$. The sugar consumption rate in $12^{\text {th }}$ hour of the growth of yeast was found to be $0.04 \mathrm{~mol}$ $\mathrm{h}^{-1}$. Therefore, the heat generation will be $652 \mathrm{~kJ} \mathrm{~mol}^{-1}$ of sugar consumed during the growth of yeast Kluyveromyces sp. IIPE 453 at $50^{\circ} \mathrm{C}$.

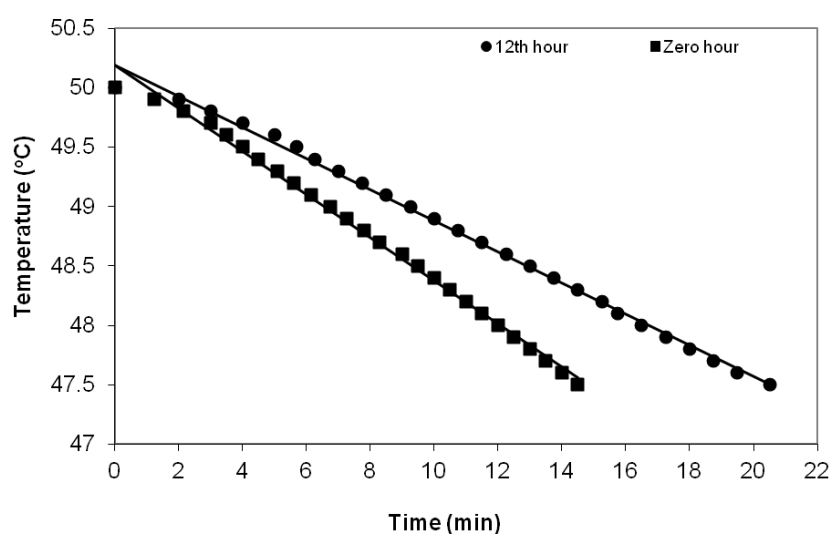

Figure 2. Temperature-time course of bioreactor during growth of thermotolerant yeast Kluyveromyces sp. IIPE453 at $50^{\circ} \mathrm{C}$ with $1 \mathrm{vvm}$ aeration

The temperature-time courses were recorded over a period of $15 \mathrm{~min}$ between zero and $24^{\text {th }}$ hour during a batch fermentation using yeast Kluyveromyces sp. IIPE453 at $50^{\circ} \mathrm{C}$. The temperature was not controlled during recording of the temperature-time course. As shown in Figure 3, the temperature was decreased with time because of high rate of heat loss to surrounding atmosphere at zero hour. The rate of heat loss was lower at $12^{\text {th }}$ hour than that of zero hour, shows the heat generation due to the ethanol fermentation. The heat generation was calculated using Eq. (6), as given in Table 1. Figure 4 shows the heat generation in corresponding to sugar consumption rate and ethanol production rate. The heat generated in ethanol fermentation using Kluyveromyces sp. IIPE453 was found to be $132.54 \mathrm{~kJ} \mathrm{~mol}^{-1}$ of sugar consumed or $67.84 \mathrm{~kJ} \mathrm{~mol}^{-1}\left(2.46 \mathrm{MJ} \mathrm{l}^{-1}\right)$ of ethanol 
produced at $50^{\circ} \mathrm{C}$. Theerarattananoon et al. [16] reported heat generation of $43-66 \mathrm{~kJ} \mathrm{~mol}^{-1}$ of sugar consumed by $S$. cerevisiae at $25^{\circ} \mathrm{C}$, which is almost half of the heat generated during ethanol fermentation using Kluyveromyces sp. IIPE453.

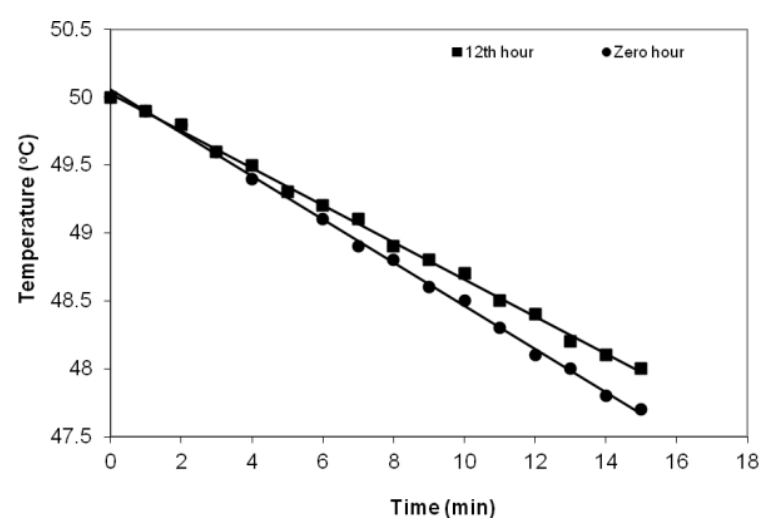

Figure 3. Temperature-time course of bioreactor during ethanol fermentation using thermotolerant yeast Kluyveromyces sp. IIPE453 at $50{ }^{\circ} \mathrm{C}$

Table 1. Variation in rate of heat generation with rates of sugar consumption and ethanol production at different times during ethanol fermentation using Kluyveromyces sp. IIPE453 at $50^{\circ} \mathrm{C}$

\begin{tabular}{cccc}
\hline $\begin{array}{c}\text { Time } \\
(\mathrm{h})\end{array}$ & $\begin{array}{c}\text { Sugar } \\
\text { consumption rate } \\
\left(\mathrm{mol} \mathrm{h}^{-1}\right)\end{array}$ & $\begin{array}{c}\text { Ethanol } \\
\text { production rate } \\
\left(\mathrm{mol} \mathrm{h}^{-1}\right)\end{array}$ & $\begin{array}{c}\text { Heat generated } \\
\left(\mathrm{kJ} \mathrm{h}^{-1}\right)\end{array}$ \\
\hline 4 & 0.09 & 0.18 & 12.6 \\
8 & 0.125 & 0.24 & 17.2 \\
12 & 0.21 & 0.41 & 27.4 \\
20 & 0.17 & 0.34 & 23.0 \\
24 & 0.15 & 0.30 & 20.1 \\
\hline
\end{tabular}
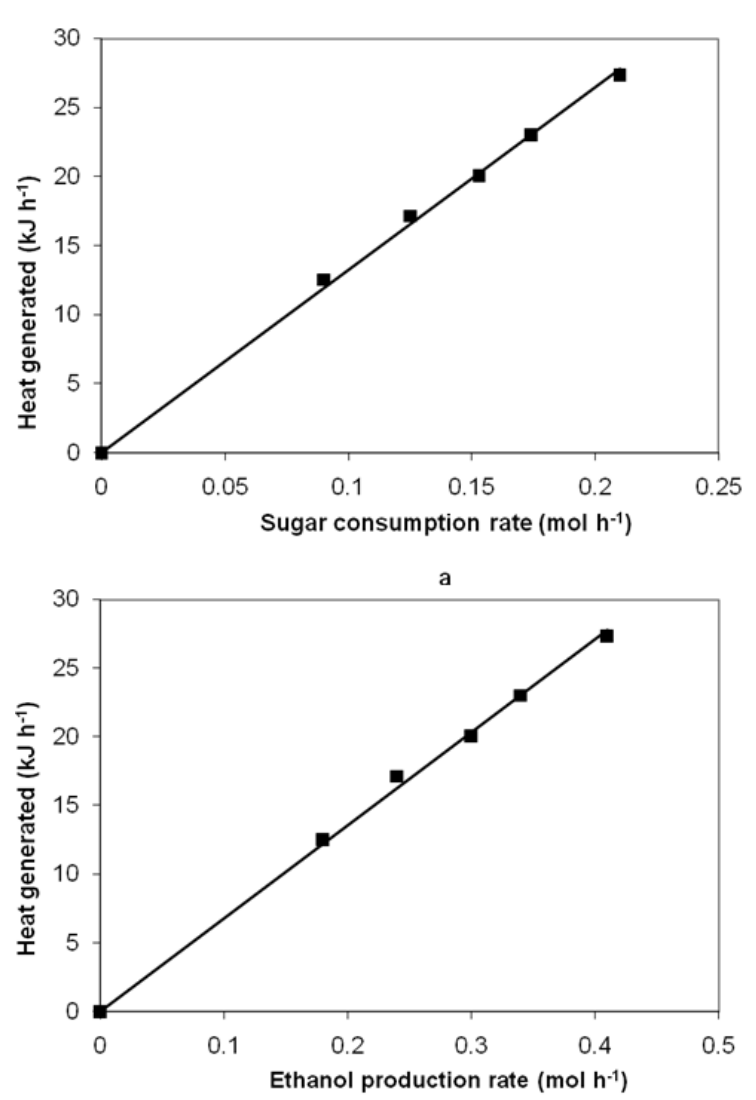

Figure 4. Heat generated during ethanol fermentation using thermotolerant yeast Kluyveromyces sp. IIPE 453 at $50^{\circ} \mathrm{C}$ at different (a) sugar consumption rates and (b) ethanol production rates
The heat loss due to bubbling air ( $1 \mathrm{vvm}$ aeration rate) and evaporation was calculated using Eq. (7), which was found to be $36 \mathrm{~kJ} \mathrm{~h}^{-1}$. The surface area of the bioreactor vessel was calculated using Eq. (14) as $0.079 \mathrm{~m}^{2}$. The heat loss due to natural convection was calculated using Eqs. (8)-(13) and found to be $187 \mathrm{~kJ} \mathrm{~h}^{-1}$. The kinematic viscosity $\left(v_{a}\right)$, thermal diffusivity $\left(\alpha_{a}\right)$ and thermal conductivity $\left(\lambda_{a}\right)$ of air at surrounding temperature of $25^{\circ} \mathrm{C}$ are used as $1.595 \times 10^{-5} \mathrm{~m}^{2} \mathrm{~s}^{-1}, 2.371 \times 10^{-5} \mathrm{~m}^{2} \mathrm{~s}^{-1}$ and $9.36 \mathrm{~kJ}$ $\mathrm{h}^{-1} \mathrm{~m}^{-1} \mathrm{~K}^{-1}$, respectively. The convection heat transfer coefficient $\left(h_{a}\right)$, thermal conductivity of glass material $(\lambda)$ and thickness of wall $(\Delta x)$ are used as $108 \mathrm{~kJ} \mathrm{~h}^{-1} \mathrm{~m}^{-2} \mathrm{~K}^{-1}$, $4.32 \mathrm{~kJ} \mathrm{~h}^{-1} \mathrm{~m}^{-1} \mathrm{~K}^{-1}$ and $0.003 \mathrm{~m}$, respectively. In actual practice, the heat loss due to natural convection was calculated from Figure 2, which was found to be $58.7 \mathrm{~kJ} \mathrm{~h}^{-}$

In case of growth, the total heat loss will be the sum of heat loss due to bubbling air, natural convection and evaporation, which was found to be $94.7 \mathrm{~kJ} \mathrm{~h}^{-1}$. For a growth of Kluyveromyces sp. IIPE453, a run of 24h [19], the total heat loss will be $2272.8 \mathrm{~kJ}$. The metabolic heat generation for $40 \mathrm{~g}(0.222 \mathrm{~mol})$ sugar will be $145 \mathrm{~kJ}$. There is huge difference between heat loss and heat generation. The heat loss due to natural convection can be minimized using insulation and/or by decreasing $\mathrm{S} / \mathrm{V}$ ratio. But heat loss due to bubbling air and evaporation cannot be controlled unless air at high temperature introduced in the reactor. The heat loss due to bubbling air and evaporation in $24 \mathrm{~h}$ will be $864 \mathrm{~kJ}$. Therefore, during growth of the yeast the heat input will be required to maintain the desired temperature in the bioreactor.

In case of fermentation, the total heat loss will be due to natural convection, which is found to be $58.7 \mathrm{~kJ} \mathrm{~h}^{-1}$. For a run of ethanol fermentation on molasses in first $32 \mathrm{~h}$, the total sugar consumption was $334 \mathrm{~g}$ or $1.86 \mathrm{~mol}$ [20]. The total heat loss in $32 \mathrm{~h}$ will be $1878.4 \mathrm{~kJ}$. The metabolic heat generation for $1.86 \mathrm{~mol}$ sugar will be $212 \mathrm{~kJ}$. There is also a huge difference between heat loss and heat generation. The heat loss due to natural convection can be minimized using insulation and/or by decreasing $\mathrm{S} / \mathrm{V}$ ratio. Therefore, no additional heat would be required to maintain the desired temperature for fermentation in the bioreactor.

In a case study of Indian distillery, fermentation of 400 $\mathrm{m}^{3}$ wort using $S$. cerevisiae completes in $32 \mathrm{~h}$ with $8 \%(\mathrm{v} / \mathrm{v})$ ethanol concentration, which requires cooling water at $25^{\circ} \mathrm{C}$ at the rate of $550 \mathrm{~m}^{3} \mathrm{~h}^{-1}$. Therefore, $550 \mathrm{~m}^{3}$ cooling water per $\mathrm{m}^{3}$ of ethanol is required to maintain temperature at $32^{\circ} \mathrm{C}$ in a bioreactor. The power requirement for cooling tower and circulating to the bioreactor is $\sim 70 \mathrm{KW} \mathrm{h} \mathrm{h}^{-1}$ or $\sim 0.07 \mathrm{~kW}^{-1}$ of ethanol produced. For a fermentation run, the cooling water is required for $20 \mathrm{~h}$, which will consume $\sim 5.04 \mathrm{MJ}^{-1}$ of ethanol produced. The energy required for fermentation and distillation is $12.63 \mathrm{MJ}^{-1}$ of ethanol [23]. Therefore, about $40 \%$ of energy utilization can be minimized by eliminating the cooling during ethanol fermentation. The metabolic heat may be sufficient to maintain the temperature of bioreactor at $50^{\circ} \mathrm{C}$.

\section{Conclusions}

The metabolic heat generated due to ethanol fermentation by thermotolerant yeast Kluyveromyces sp. 
IIPE453 was higher than reported for mesophilic yeast $S$. cerevisiae. Ethanol fermentation using thermotolerant yeast has the advantage over mesophiles in terms of minimization of the cooling water requirement. Therefore, no additional heat may be required to maintain the temperature in fermentation process by thermotolerant yeast at $50^{\circ} \mathrm{C}$. In addition, using thermotolerant yeast for ethanol fermentation power requirement for maintaining temperature in a bioreactor can be minimized, which accounts $\sim 40 \%$ of total power requirement in fermentation and distillation using mesophiles. The current study is a lab-scale study and future study on a large-scale is required to validate the results.

\section{Acknowledgements}

We thank Dr M.O. Garg, Director IIP, Dehradun for his valuable suggestion and encouragement to carry out this research work. One of the authors (Sachin Kumar) gratefully acknowledges Senior Research Fellowship awarded by Council of Scientific and Industrial Research (CSIR), India.

\section{Nomenclature}

$A \quad$ Surface area $\left(\mathrm{m}^{2}\right)$

$C_{p} \quad$ Specific heat $\left(\mathrm{kJ} \mathrm{kg}^{-1} \mathrm{~K}^{-1}\right)$

D Diameter of cylindrical section of bioreactor (m)

$d T / d t$ Slope of the curve between temperature and time

$g \quad$ Gravity constant $\left(\mathrm{m} \mathrm{s}^{-2}\right)$

$h \quad$ Height of the broth level in bioreactor (m)

$h \quad$ Height of the level of broth in cylindrical section (m)

$h_{a} \quad$ Convection heat transfer coefficients for air $(\mathrm{kJ} \mathrm{h}$ ${ }^{1} \mathrm{~m}^{-2} \mathrm{~K}^{-1}$ )

$h_{b} \quad$ Convection heat transfer coefficients for broth $\left(\mathrm{kJ} \mathrm{h}^{-1} \mathrm{~m}^{-2} \mathrm{~K}^{-1}\right)$

$h_{d} \quad$ Height of the bottom of bioreactor (m)

$\Delta H r$ Heat generated due to biological reactions $(\mathrm{kJ})$

M Mass of fermentation/growth medium solution $(\mathrm{kg})$

$\mathrm{Nu} \quad$ Nusselt number

$\mathrm{Pr} \quad$ Prandtl number

$Q \quad$ Heat generated $(\mathrm{kJ})$

$\dot{Q} \quad$ Heat generated per unit time $\left(\mathrm{kJ} \mathrm{h}^{-1}\right)$

$Q_{\text {loss }}$ Total heat loss from the reactor $(\mathrm{kJ})$

$\dot{Q}_{a} \quad$ Heat loss per unit time due bubbling air and evaporation $\left(\mathrm{kJ} \mathrm{h}^{-1}\right)$

$\dot{Q}_{c} \quad$ Heat loss per unit time due natural convection (kJ $\left.\mathrm{h}^{-1}\right)$

$R \quad$ Radius of cylindrical section of bioreactor (m)

$r_{d} \quad$ Radius of sphere of the bottom of bioreactor (m)

$R a$ Rayleigh number

$T_{a} \quad$ Temperature of surrounding atmosphere $(\mathrm{K})$

$T_{b} \quad$ Temperature of broth (K)

$\Delta T$ Temperature difference between the reactor surface and the surrounding atmosphere $(\mathrm{K})$

$U$ Overall heat transfer coefficient $\left(\mathrm{kJ} \mathrm{h}^{-1} \mathrm{~m}^{-2} \mathrm{~K}^{-1}\right)$

$\Delta x \quad$ Thickness of wall (m)

Symbols
$\Lambda \quad$ Thermal conductivity of material $\left(\mathrm{kJ} \mathrm{h}^{-1} \mathrm{~m}^{-1} \mathrm{~K}^{-1}\right)$

$\lambda_{a} \quad$ Thermal conductivity of the air $\left(\mathrm{kJ} \mathrm{h}^{-1} \mathrm{~m}^{-1} \mathrm{~K}^{-1}\right)$

$v_{a} \quad$ Kinametic viscosity of air $\left(\mathrm{m}^{2} \mathrm{~s}^{-1}\right)$

$\alpha_{a} \quad$ Thermal diffusivity of air $\left(\mathrm{m}^{2} \mathrm{~s}^{-1}\right)$

Subscripts

A Air

B Broth

C Natural convection

D Bottom of bioreactor

\section{References}

[1] Kosaric, N, "Ethanol- potential source of energy and chemical products," In: Rehm HJ, Reed G (eds) Biotechnology, Vol 6, Products of Primary Metabolism, 2nd edn. VCH Publishers Inc, Germany, 121-203, 1996.

[2] Abdel-Fattah, W.R., Fadil, M., Nigam, P. and Banat, I.M, "Isolation of thermotolerant ethanlogenic yeasts and use of selected strains in industrial scale fermentation in an Egyptian distillery," Biotechnology and Bioengineering, 68 (5), 531-535, Jun.2000.

[3] Lin, Y. and Tanaka, S, "Ethanol fermentation from biomass resources: current state and prospects," Applied Microbiology and Biotechnology, 69(6), 627-642, Feb.2006.

[4] Phisalaphong, M., Srirattana, N. and Tanthapanichakoon, W, "Mathematical modeling to investigate temperature effect on kinetic parameters of ethanol fermentation," Biochemical Engineering Journal, 28(1), 36-43, Feb.2006.

[5] Kumar, S., Singh, S.P., Mishra, I.M. and Adhikari, D.K, "Recent advances in production of bioethanol from lignocellulosic biomass," Chemical Engineering and Technology, 32(4), 517-726, Apr.2009.

[6] Anderson, P.J., McNeil, K. and Watson, K, "High-efficiency carbohydrate fermentation to ethanol at temperatures above $40^{\circ} \mathrm{C}$ by Kluyveromyces marxianus var. marxianus isolated from sugar mills," Applied and Environmental Microbiology, 51(6), 13141320, Jun.1986.

[7] Lynd, L.R, "Production of ethanol from lignocellulosic materials using thermophilic bacteria: Critical evaluation of potential and review," In: Fiechter A (ed) Advances in Biochemical Engineering/Biotechnology, Vol 38, Lignocellulosic Materials, Springer, New York, 1-52, 1989.

[8] Banat, I.M., Nigam, P., Singh, D., Marchant, R. and McHale, A.P, "Review: Ethanol production at elevated temperatures and alcohol concentrations: Part I - Yeasts in general," World Journal Microbiology and Biotechnology, 14(6), 809-821, Nov.1998,

[9] Sree, N.K., Sridhar, M., Rao, L.V. and Pandey, A, "Ethanol production in solid substrate fermentation using thermotolerant yeast," Process Biochemistry, 34(2), 115-119, Feb.1999.

[10] Koskinen, P.E.P., Beck, S.R., Örlygsson, J. and Puhakka, J.A, "Ethanol and hydrogen production by two thermophilic, anaerobic bacteria isolated from icelandic geothermal areas," Biotechnology and Bioengineering, 101(4), 679-690, Nov.2008.

[11] Lee, J, "Biological conversion of lignocellulosic biomass to ethanol," Journal of Biotechnology, 56, 1-24(1), Jul.1997.

[12] Limtong, S., Sringiew, C. and Yongmanitchai, W, "Production of fuel ethanol at high temperature from sugar cane juice by a newly isolated Kluyveromyces marxianus," Bioresource Technology, 98(17), 3367-3374, May.2007.

[13] Plesser, T., Müller, S.C., Hess, B., Lamprecht, I. and Schaarschmidt, B, "Periodic heat production by oscillating glycolysis in a cytoplasmic medium extracted from yeast," FEBS Letters, 189(1), 42-44, Sep.1985.

[14] von Stockar, U., Duboc, P., Menoud, L. and Marison, I.W, “Online calorimetry as a technique for process monitoring and control in biotechnology," Thermochimca Acta, 300 (1-2), 225-236, Oct.1997.

[15] Meier-Schneiders, M. and Schäfer, F, "Quantification of small enthalpic differences in anaerobic microbial metabolism a calorimetry-supported approach," Thermochimca Acta, 275(1), 116, Apr.1996.

[16] Theerarattananoon, K., Lin, Y.H. and Peng, D.Y, "Metabolic heat evolution of Saccharomyces cerevisiae grown under very-high- 
gravity conditions," Process Biochemistry, 43(11), 1253-1258, Nov.2008.

[17] Türker, M, "Development of biocalorimetry as a technique for process monitoring and control in technical scale fermentations," Thermochimca Acta, 419(1-2), 73-81, Sep.2004.

[18] Chongvatana, P, "Cooling system in ethanol plant with starch base feedstock," ASHARE Thailand Chapter Journal, 1, 30-33, 2007 2008.

[19] Kumar, S., Singh, S.P., Mishra, I.M. and Adhikari, D.K, "Ethanol and xylitol production from glucose and xylose at high temperature by Kluyveromyces sp. IIPE453," Journal of Industrial Microbiology and Biotechnology, 36(12), 1483-1489, Dec.2009.
[20] Kumar, S., Singh, S.P., Mishra, I.M. and Adhikari, D.K "Feasibility of ethanol production with enhanced sugar concentration in bagasse hydrolysate at high temperature using Kluyveromyces sp. IIPE453," Biofuels, 1(5), 697-704, Sep.2010.

[21] Colombié, S., Malherbe, S. and Sablayrolles, J.M, "Modeling of heat transfer in tanks during wine-making fermentation," Food Control, 18(8), 953-960, Aug.2007.

[22] Lienhard, J.H. and Leinhard, J.H, A heat transfer textbook, Phlogiston Press Cambridge, Massachusetts, USA, 2004.

[23] Khatiwada, D. and Silveira, S, "Net energy balance of molasses based ethanol: The case of Nepal," Renewable and Sustainable Energy Reviews, 13(9), 2515-2524, Dec.2009. 